\title{
New Times, New Crimes: Notes on the Depillarization of the Criminal Justice System
}

\author{
Roger Matthews ${ }^{1}$ (D) \\ Published online: 9 March 2020 \\ (C) The Author(s) 2020
}

\begin{abstract}
A great deal has been written about the changing nature and direction of criminology over the past two decades, including claims that we are moving into a "new penology." Many of these claims are suggestive rather than authoritative. In contrast to most commentaries on the subject, this article provides longer historical overview and attempts to sketch out how the central structures or "pillars" of the criminal justice system have become weakened and eroded over the last 200 years and how the emergence of body of "new crimes" and their regulation is challenging what might be called the "old criminology." The emergence of new relations between victims and offenders, criminal justice and social justice, as well as the development of innovative modes of regulation are, it is argued, changing the social and criminological landscape. This raises issues of theory and practice that challenge traditional conceptualisations of crime and punishment.
\end{abstract}

\section{Introduction}

This article is divided into four parts. The first draws on the work of Foucault (1977) and his incisive depiction of the emergence of the modern criminal justice system, focusing in particular on the triangulated relationship between the prison, the police, and the construction of the criminal classes. The second part outlines what is referred to as the "depillarization" of the criminal justice system over the last 100 years or so involving the gradual weakening and erosion of these three "pillars." The third part considers the development of a selected range of "new crimes"-cybercrime, environmental crime, and terrorism - and examines the ways in which the strategies that are being developed to respond to these issues involve a significantly different response than that which has traditionally been used to deal with "normal crime" and "street crime." The final part involves a discussion of these developments and raises questions about their implications and significance for theory and for practice.

Roger Matthews

R.A.Matthews@kent.ac.uk

1 University of Kent, Canterbury, UK 


\section{The Social Construction of the Modern Criminal Justice System}

Anyone who has read Michel Foucault's Discipline and Punish: The Birth of the Prison (1977) will know that this book effectively transforms the way that we understand crime and punishment. Most commentators on this text, however, tend to be drawn in one of two main directions. Either they are attracted by his incisive analysis of discipline or they are fascinated by the powerful discussion of the panopticon and spatial regulation. Both these issues are, of course, important, but arguably the most significant section of the book is the chapter that deals with the formation of the modern criminal justice system at the end of the eighteenth century. In this chapter-the first chapter of Part II-Foucault outlines how a range of transgressions become redefined in that period and how the activities of the poor involving theft, vagrancy, and other public order acts became the object of criminal sanctions to be dealt with by the criminal court, attracting a range of punitive sanctions (particularly imprisonment), while the transgressions of the middle and upper classes came under the jurisdiction of specialist courts (with the fines as the primary sanction). As Foucault (1977: 87) states:

[Or to put it another way] the economy of illegalities was restructured with the development of capitalist society. The illegality of property was separated from the illegality of rights. This distinction represents a class opposition because on the one hand, the illegality that was to be most accessible to the lower classes was that of property - the violent transfer of ownership - and because, on the other, the bourgeoisie was to reserve for itself the illegality of rights. The possibility of getting around its own regulations and laws, of ensuring for itself an immense sector of economic circulation by a skilful manipulation of gaps in the law-gaps that were foreseen by its silences, or opened up by de facto tolerance.

Foucault did not doubt that the modern criminal justice system was a system of "class justice" that conveniently redistributed the range of illegalities in a way that systematically penalized the poor, while tolerating the excesses of the middle and upper classes. In addition, Foucault makes the important point that the formation of the modern criminal justice system should be seen in terms of a triangulated relationship between the prison, the police, and the "criminal classes." The system was conceived of in terms of these three structures-or pillars-providing the basis for an effective system of sorting, classifying, categorizing, and ultimately managing illegalities (Foucault 2009).

The emergence of the newly formed uniformed police in the first half of the nineteenth century was a response to the deep rupture in class relations in the United Kingdom (UK) (Storch 1975). There were deepening social and geographical divisions between the rich and the poor and the growing feeling that the "licentiousness" (cockfighting, drinking, gambling, and prostitution) of the poor and "dangerous classes" required urgent moral reform and social discipline. Consequently, there was growing pressure to create an agency that could prevent and detect crime, while maintaining constant surveillance upon all facets of poor- and working-class communities. Although drawn mainly from the lower rungs of the working class, the newly established police force was seen as both a protective and political force, generating both qualified support from the "respectable" working class and widespread condemnation and suspicion.

A similar dynamic was evident in the nineteenth-century United States (US), with some elements of the "London Model" being incorporated in US policing systems (Lane 1992). Apparently, there was little resistance to the progressive militarization and arming of the 
police - as many patrolmen began to carry pocket revolvers in the 1850s-but there was considerable public resistance to the adoption of blue uniforms. As in England, the police in the US in the nineteenth century were charged with dealing with citizens' complaints and requests, as well as patrolling poor- and working-class communities, while enforcing certain sections of the criminal law. Like their English counterparts, American cops were typically recruited from among white working-class men, although this did not ensure that they represented the interests of their "class." The policing of the poor and marginalized was conditioned by concerns with immigrant populations to a much greater degree in the US than in England.

The development of the modern prison in Europe in the early nineteenth century also displayed very specific class dimensions. These institutions provided punishments of "measured time," but unlike their predecessors, such as debtors prisons, these modern prisons were reserved almost exclusively for the poor, the marginalized, and the economically excluded population - the underclass (Ignatieff 1978). One of the most influential figures in the nineteenth century, Mayhew (1961), found that in the 1850s, almost half of the population of Colebatch Fields Prison was incarcerated because they were unable to pay fines in police courts.

The nineteenth-century prison was not without its critics. Its failure to reform offenders, the enormous expense involved in housing them, and its inability to control crime, coupled with charges of administrative incompetence and corruption, brought the prison into dispute by the end of the century. But as Ignatieff (1978: 210) has argued, imprisonment continued to maintain a semblance of support, although its appeal rested not so much on its capacity to control crime:

Instead, its support rested on a larger social need. It had an appeal because reformers succeeded in presenting it as a response, not merely to crime, but to the whole social crisis of the period and as part of a larger strategy of political, social, and legal reform designed to re-establish criticised for its functional shortcomings, the penitentiary continued to command support because it was seen as an element of a larger vision of order that by the 1840 s commanded the reflexive assent of the propertied and the powerful.

In this context, crime came to be viewed as less of an example of human fallibility or wickedness and more as an indictment of society in crisis. The growth of masterless urban populations and the resulting estrangement of the rich and the poor allowed reformers to draw a connection between the rise of property crime and the erosion of traditional "paternal" social relationships. The emphasis on the reformative ideal had the attraction of implying that the punisher and the punished could be brought back together in a shared moral universe. It spoke to the heartfelt middle-class desire for a social order based on deferential reconciliation (Storch 1975).

According to Rusche and Kirchheimer (2003), judicial administration at the end of the eighteenth century was placed firmly in the hands of the propertied classes. The propertied classes saw in the administration of the criminal justice system the common interest of all the upper strata - the conservation of property. The judiciary claimed independence which was seen to have two main functions. Positively, it supported the ideology of equality before the law; negatively, it concealed the power of the law-making judge.

Thus, the modern criminal justice system was constructed as a class-based system with crime being associated with the transgressions of the poor and the marginalized-the underclass-who were the primary object of police activity. Imprisonment was reserved almost exclusively for this group, who in many cases were imprisoned in this period for 
relatively minor offenses of theft and disruption of the public order. The legal system conveniently distinguished between crimes of property and crimes of fraud-whereby the former fell under the jurisdiction of criminal courts (and often resulted in imprisonment), while the latter was dealt with in specialist courts (which imposed mostly fines for the convicted). At the same time, members of the judiciary were drawn mainly from the upper strata, claiming independence and the authority to shape and interpret the law creatively.

\section{The Depillarization of the Criminal Justice System}

Over the past 200 years, this triangulated relationship and the "pillars" on which it rested (the prison, the police, and the construction of the criminal classes) have undergone an extensive process of weakening and erosion. During the 1980s, Dutch sociologists and criminologists used the term, "depillarization," to describe what they saw as the erosion of the central sociopolitical "pillars" of Dutch society, which they argued was having a profound effect on the stability of the social system (Bryant 1981; Downes 1988). In many respects, this term captures the changing nature of the three structures outlined above- the prison, the police, and the criminal classes. Each of these structures has undergone major changes with the consequence that they have become seriously weakened and appear to be in a state of decay. Arguably, these structures were always fragile and unstable, although they have continued to function.

\section{The Crisis of Imprisonment}

The modern prison, it has been argued, has been in a state of "crisis" since its inception (Foucault 1977; Ignatieff 1978; McLennan 2008). For the most part, the term "crisis" is used by academics and the media as a synonym for the various tensions and problems facing imprisonment, such as overcrowding, poor conditions, recidivism, and violence. But because these issues are an endemic feature of the modern prison system - which nevertheless persists and, in some cases, continues to expand-the explanatory value of the term "crisis" in this context is difficult to determine.

Thus, rather than seeing the notion of the "crisis of imprisonment" in terms of discrete events, it may be more analytically appropriate to theorize this process. One obvious point of reference is Marx's theory of crisis of capitalist development. For Marx, the capitalist crisis should be understood not in terms of events or specific issues, such as unemployment, poverty or deprivation, but in terms of the ongoing contradictory tendencies involving a number of conflicting forces that lead capitalism into recurring breakdowns. Offe (1984: 37), in his analysis of the crisis of the welfare state, adopts such a method, aiming to identify the underlying mechanisms that generate crisis tendencies:

The alternative approach conceives crisis not at the level of events but rather at the superordinate level of mechanisms that generate 'events'. According to this second definition crises are processes that violate the 'grammar' of social processes. Such a definition favours a processual concept of crisis. Crises are developmental tendencies that can be confronted with 'counteracting tendencies', which means that the outcome of crises is quite unpredictable. [emphases in original]

The implications of this approach are that just as it is a central role of government is to manage the contradictions of capitalist accumulation in order to try to avoid a financial collapse, so the central task of prison administrators is to manage the ongoing crisis 
tendencies within the prison system. This crisis is based on the contradictory functions or imperatives of imprisonment-deterrence, incapacitation, rehabilitation, and retribution. An increased emphasis on one function, such as incapacitation, tends to work to the detriment of rehabilitation, and by the same token, an increased emphasis on rehabilitation is seen to undermine the objective of deterrence and retribution. As a result of trying to balance these objectives, policymakers tend to consistently change the dominant justification for the use of imprisonment from one period to another.

Viewed historically, it is evident that the introduction of the "welfare sanction" and more inclusive community-based forms of punishment at the beginning of the twentieth century was a response to the deepening prison crisis at the end of the nineteenth century, combined with the shift toward welfare capitalism (Donzelot 1997; Garland 1981; Rusche and Kirchheimer 2003). More recently, the rise of the so-called decarceration movement in the 1960s and 1970s encouraged the development of a range of "alternatives" to custody. In subsequent decades, other penal strategies have been introduced, including privatization and risk assessment, in order to depoliticize the penal sphere, rendering it more independent of the State and, at the same time, leaving the State less accountable.

In many respects, the contradictions within the penal system have become more evident in recent years as the workings of the prison have become more visible (Jacobs 1978). The growth of media and research reports has highlighted repeatedly the limitations and failures of deterrence, incapacitation, and rehabilitation. There appears to be a growing consensus that very little works either to reform offenders or to reduce crime (Durlauf and Nagin 2011). This seems to be the case whether prison numbers are increasing or decreasing.

For much of the twentieth century, the main emphasis was to reform offenders both within the confines of the prison and with the help of support agencies, such as probation, parole and a separate system of juvenile justice. In the early 1970s, however, the notion of rehabilitation came under fire on a number of fronts. It was blamed by liberals for allowing the state to act coercively against offenders and was criticized by conservatives for allowing the state to treat offenders too leniently (Bottoms and Preston 1980). The influential "nothing works" article by Martinson (1974) served to confirm the growing consensus that, in terms of recidivism, rehabilitation was not effective.

Consequently, the following two decades were dominated by a political and policy shift toward a conservative-led "get tough" agenda centered around a combination of incapacitation and deterrence, epitomized in Murray's (1997) claims that prisons could be made to work if "used with sufficient ruthlessness" and if punishment were to become more certain and more harsh. In this period, there was a growing emphasis on "just deserts" and that the penalty should be proportionate to the harm committed by the offender. This resulted in increased use of mandatory and determinate sentencing, longer sentences, and greater overcrowding, combined with an emphasis on penal austerity and a skepticism about the use of parole and early release.

The underlying logic of incapacitation was the belief that it would take offenders off the streets, although some criminologists claimed that incapacitating offenders would not only reduce crime but could also save money. Imaginative calculations were presented to show the financial benefits of incapacitation. Needless to say, these calculations were either inaccurate or exaggerated (Currie 1998). Critics of incapacitation pointed to the largely negative effects of simply "warehousing" prisoners and creating "schools of crime." Some commentators also pointed to the collateral consequences of mass incarceration and the effects on families and dependents (Mauer and Chesney-Lind 2003; Turanovic et al. 2012; see also Brisman 2004). Other research revealed that the strategy of incapacitation involved locking up many offenders who had passed their peak of offending and that the prison 
system was increasingly incarcerating more minor and aging offenders. The available evidence on the crime reduction effects of prison is largely inconclusive, but it is evident that the extremely high social and economic costs of incapacitation could be sustained only for a limited period. As a result, there was a shift toward a strategy of specific incapacitation designed to focus on the more hardened and dangerous offenders. Predicting dangerousness proved to be difficult, however, and was found to be fraught with methodological problems and unreliable conclusions (Piquero and Blumstein 2007).

The perceived limitations of incapacitation provided an impetus among some criminologists and policymakers toward support for a strategy of deterrence-both general and specific - which was held to be a more effective approach to crime reduction (Nagin 1998). Like incapacitation, the policy of deterrence has a fairly immediate commonsense appeal but, again, the available evidence is highly ambiguous and contested and there is a widely shared belief that penalty increases have marginal deterrent effects (Tonry 2008). It is recognized that different individuals have a different susceptibility to legal threats and that, in many cases, offenders either do not think that they will be caught or they are not aware of the relevant punishments. For those incarcerated, the specific deterrent effects of penal servitude are often outweighed by the increased pains of imprisonment and subsequent marginalization.

In response to the perceived limitations and often counterproductive implications of these various policies, there has been, over the last decade or so, something of a revival of rehabilitation, although it has taken new forms (Robinson 2008). There has been a growth in treatment programs with a particular emphasis on developing the cognitive skills of offenders. Often linked to notions of risk, the interventions aim to target the "criminogenic needs" of offenders. Particularly, influential has been the risk-need-responsivity (RNR) model, developed by Andrews and Bonta (2010), which claims to reduce recidivism rates significantly by helping offenders to "think straight." The RNR model, however, in turn, has been subject to criticism, particularly in relation to its risk prediction procedures, and issues remain as to what type of needs should be addressed (Ward and Maruna 2008). Critics argue that focusing on risk reduction is unlikely to motivate offenders to make the major changes required to reduce their chances of reoffending and that the RNR model should be replaced, or at least supplemented, by a strengths-based "Good Lives Model," which focuses primarily on the "deficits" of offenders; its goal is to provide a future-orientated approach which aims to build upon the positive attributes and capacities of offenders.

These tensions and disputes about the justification for imprisonment remain unresolved. The debate oscillates from one option to another and from "getting tough," on the one hand, to attempts at rehabilitation and resettlement, on the other. At the moment, there is increasing pressure to downsize the scale of imprisonment and to find other less destructive ways of regulating offenders (Clear and Frost 2014).

\section{The End of Policing?}

It has been widely recognized for some time in criminological circles that the police are not very effective at reducing or solving crimes (Bayley 1994). Conservatives and liberals alike have expressed deep reservations about the purpose and effects of policing. In their classic article on "broken windows," the conservative theorists, Wilson and Kelling (1982), provided a powerful critique of the police's achievements in terms of crime control, in general, and in relation to "fire brigade" policing, in particular. In contrast to these dominant 
styles of policing, they advocated a greater emphasis on public order policing and a crackdown on incivilities.

Various critics have rejected Wilson and Kelling's approach to policing on the basis that it is anachronistic and reduces police accountability. Moreover, commentators have argued that the "broken windows" perspective justifies an unnecessarily heavy-handed approach to minor infractions that would be better addressed in more constructive ways (Harcourt 1998; Kinsey et al. 1986; Matthews 1992). There remains, however, a fundamental tension in modern policing between protecting the public and responding to victims, on the one hand, and controlling public demonstrations-often in brutal and authoritarian ways - on the other.

Some years ago, Bayley (1994) asked the critical question: "What do the police do?" His answer was, first and foremost, that they do not prevent crime. Consistent with Wilson and Kelling's (1982) claim, Bayley points out that research has consistently failed to show that motorized uniformed patrols have any significant impact on crime and victimization. Patrolling by foot may produce a degree of reassurance, but it also has little impact on crime, while rapid response units invariably arrive too late. Moreover, criminal investigations form a small part of uniformed police work and even among dedicated detectives, arrest rates and "clear-up rates" are low. In fact, the critical ingredient in solving crimes is information and reports provided by the public.

Only a quarter of all calls to the police are about crime, and most of these incidents are relatively minor. When not "fighting crime," the police are involved primarily in order maintenance. The most difficult conflict situations that the police handle on a routine basis are disputes within families. Arrests are made only rarely. For the most part, crimes are resolved quickly or not at all. In order to increase clearance rates, detectives work hard to get "secondary clearances."

Drawing on the work of Bayley, Vitale (2017) claims that, in the US, uniformed officers make relatively few arrests each year and that felony arrests of any kind are a rarity for uniformed officers. Vitale (2017:31) adds:

When a patrol officer actually apprehends a violent criminal in the act this is a major moment in his career. The bulk of police officers work in patrol. They take reports, engage in random patrol, address parking and driving violations and noise complaints, issue tickets, and make misdemeanour arrests for drinking in public, possession of small amounts of drugs, or the vague "disorderly conduct."

According to Vitale, detectives spend much of their time taking reports of crimes that they never solve and, in many cases, do not even investigate.

In the UK, "clear-up rates" have also been plummeting despite the decrease in recorded crime levels in England and Wales. In 2012, only 27\% of crimes were solved (Whitehead 2012). This is the lowest rate since 2006-2007. In 2017, just 4\% of robberies and 3\% of burglaries were "cleared up" in England and Wales, while three-quarters of theft offenses were closed without a suspect being identified. Of almost one and a half million violent and sexual offenses recorded in 2017 , only $8 \%$ were solved. The police are now strategically "screening out" cases such that just over a quarter of all crimes reported are not fully investigated. Offenses, such as car crime, criminal damage, 
and theft, are most heavily "screened out" and, in some police forces areas, as many as $50 \%$ of reported cases are not investigated fully (Dearden 2018; Milkhailova 2018).

There have also been growing concerns over the past few years about how the police record crime. A report by Her Majesty's Inspectorate of Constabulary (HMIC) ${ }^{1}$ in 2014, for example, concluded that 1 in 5 offenses that should have been recorded by the police were not. This meant that some 800,000 crimes reported to the police are not recorded each year. The problem was found to be the greatest for victims of violence against the person and sexual offenses, where the under-recording rates were found to be $33 \%$ and $26 \%$, respectively. The police have also been accused of "massaging" figures in order to meet set targets. As a consequence, the police data in England and Wales have been stripped of their national statistics status. Some offenses are being re-categorized in order to remove them from the books, while some police officers have been accused of persuading prisoners to admit to unsolved crimes in order to meet detection targets (Laville 2012).

A recent report by the House of Commons Select Committee (HASC), entitled Policing for the Future (2018), claimed that police forces "are failing to meet the challenge of the digital age" and "above all policing is suffering from a complete failure of leadership" and is "in danger of becoming irrelevant." HASC was extremely concerned with the substantial decrease in police numbers and funding cuts. Police force funding decreased in real terms between 2010 and 2017, while the police workforce was reduced by 37,400 between March 2010 and March 2015-a 16\% cut in police numbers. Of particular concern has been the decrease in "bobbies on the beat," including a 35\% decrease in neighborhood policing posts that were originally introduced to provide community reassurance.

Over the past two or three decades, the police monopoly on public safety has been eroded (Stenning 1989). Currently, there are twice as many private security agents as public police. Public police have been replaced in banks, office buildings, shopping malls, stores, and the like (Shearing 1992). In 2017, there were 75,000 full-time staff members in supporting roles in England and Wales, including civilian staff, police community support officers, and traffic wardens (Hargreaves et al. 2018). Across all forty-three forces in England and Wales, the number of civilian staff members virtually doubled between 2000 and 2019. There are other signs that public confidence in the police is declining. Over the past few years, we have seen growth in self-protection activities on the part of communities, with neighborhood watch and citizen foot patrols.

The remarkable reduction in recorded crime over the past two decades in a number of different countries has had a significant impact on policing. Some commentators have suggested that policing has played a major role in achieving this decrease. Community policing, problem-solving policing, zero-tolerance policing, reassurance policing, and multiagency policing, as well as the concentration on hot spots and disorder, have all been presented as the basis for a drop in crime (Millie and Herrington 2005). As Karmen (2000) has pointed, however, crime decreased in most American cities irrespective of the policing strategies that were adopted, and he has suggested that the changing patterns of drug use and immigration, economic recovery, and the decline in the juvenile population, as well as the greater securitization of public space, were probably the main factors involved.

The reduction in volume crime, such as burglary, car crime, and theft, has reduced pressure on the police and impacted their work priorities and routines. Importantly, the decrease in the high number of street crimes, which has been the mainstay of uniformed

\footnotetext{
1 In July 2017, HMIC became responsible for fire and rescue services, leading to a change in its name to Her Majesty's Inspectorate of Constabulary and Fire \& Rescue Services (HMICFRS).
} 
policing for many years, combined with their dwindling numbers in the UK and poor "clear-up rates," raises questions about the role of traditional uniformed police. The pressure to deal with other transgressions with which the police have less experience and motivation has resulted in predictably limited effectiveness. The manipulation of crime data has seriously damaged the credibility of the police in official circles and reduced public trust and confidence. It now seems that the response to crime is no longer determined by its seriousness, prevalence, or impact on the victim, but on policing priorities and targets. Not surprisingly, politicians and policymakers have scrutinized police budgets. This reduction in resources and, by implication, official support is more than a cost-saving exercise, however. Money could have been saved in other ways, and thus the reduction in resources can be seen as a deliberate neoliberal strategy of minimal statism and the unleashing of market forces encouraging the privatization, the responsibilization, and the pluralization of regulation-particularly as the upper classes have become increasingly isolated and protected from the declining forms of street crime.

\section{The Decline of Crime}

The meaning and definition of "crime" has been the center of an ongoing debate in criminology for the last hundred years. For much of the period, there has been a split in the criminological literature between those who see crime as an act (or omission) and those that see it as a reaction. For some, the formal legal definition offered by Tappan (1947) provided the basis of understanding, although this definition was called into question by Sutherland's (1949) "Is White Collar Crime, Crime?" The answer to Sutherlands query was historical not empirical, but the impact of the question was to generate some uncertainty about why criminological investigation should be restricted to a limited range of transgressions.

Another landmark intervention was the publication of Hulsman's (1986) classic article on critical criminology, in which he claimed that the concept of "crime" had no ontological integrity. This article fed the intellectual desires of abolitionists, labeling theorists, social constructionists and, some years later, zemiologists (discussed below). Hulsman's article suggested that crime was an arbitrary construction and that it, like the criminal justice system that supported it, could be challenged and potentially transformed.

Most recently, a growing body of zemiologists have claimed that crime is a "myth" and have suggested that the broader concept of "harm" should replace the notion of "crime" (Hillyard et al. 2004). These zemiologists suggest that "crime" is a too narrow concept compared to the more all-encompassing concept of "harm," and they also point out that certain harms have more detrimental effects on individuals, communities, and society, in general, than those referred to as "crime" by statute. Indeed, among criminologists, there is emerging a distinction between those who reject the notion of "crime" and pursue some form of "anti-criminology" and those that adopt a fairly commonsense notion of "crime," which normally means restricting their studies to the study of "street crime" and its associated forms of victimization. Even among those who work with a taken-for-granted notion of crime, however, the recent remarkable decrease in recorded crime has shaken some of their assumptions and questioned their theories.

Criminologists were never particularly good at explaining the rise in crime and have proved to be no better at explaining the decrease (Young 1994). Farrall (2013) identified five tests that any credible explanation of the crime drop should meet and he argued that 
only the "security hypothesis" meets all five of these criteria. Although the security hypothesis goes some way to explain the decrease in property crime-particularly car crime-it provides a much less convincing explanation of the decrease in violent crime.

Some criminologists, unsurprisingly, have questioned the reliability of the available crime data and suggested that the decrease in recorded crime may be a product of dubious methods of data collection and interpretation. Apart from pointing to the unreliability of police data in England and Wales, criminologists have also questioned the reliability of the Crime Survey for England and Wales (CSEW). A report in Civitas, the multidisciplinary journal, estimated that over 3 million offenses that take place in England and Wales each year do not appear on the CSEW, mainly because the data are capped (Farrall and Pease 2007). That is, the research placed an arbitrary limit on the number of incidents that each respondent was allowed to report. Similarly, in an attempt to re-examine the trends in violent crime in England and Wales, Walby and colleagues (2016) have reworked the capped data from the CSEW and developed an estimate of the three-year average in order to provide a more reliable measure of violence over time. By adopting this approach, the authors conclude that in contrast to the claims made by CSEW that violence is stabilizing or decreasing, some forms of violence have actually been increasing - particularly violence against women.

Whatever the uncertainties and limitations of the main data sources, there can be little doubt that some forms of crime and victimization have decreased in a number of countries over the past two decades. Arguably, this decrease has had an impact on public opinion. Data released from the Office of National Statistics, which are based on the findings of the CSEW, indicate that between 2009 and 2016, the percentage of adults who think that crime has gone up in the past few years has decreased from just over $80 \%$ to $60 \%$. Similarly, the report indicated that the percentage of the population that thought that they might be a victim of crime decreased from $27 \%$ to approximately $18 \%$ over the same period (Elkin 2018). Significantly, the issue of crime has been sidelined during the last two presidential elections in the US and from the last two general elections in the UK.

As the concern with the crime has decreased, there has been a simultaneous focus on antisocial behavior. A prominent response to this development has been to see it simply as an unwarranted and unnecessary extension of control by the State. An alternative reading, however, is to see the growing preoccupation with antisocial behavior as a critique of the traditional operation of the criminal justice system, which is cumbersome, inefficient, and slow. Moreover, it has been pointed out that whereas crimes tend to be specific events that occur with different degrees of frequency, forms of antisocial behavior tend to be continuous, resulting in a greater negative impact on the day-to-day life of communities (Kelling 2001).

As Crawford (2009) has argued, the introduction of the antisocial behavior agenda has created new powers and regulatory tools that represent a major challenge to the traditional conceptions of criminal justice. This new agenda is designed to circumvent established regulatory ideas, such as due process, proportionality, and special protections traditionally afforded to young people. This form of micromanagement advocates compacts, conditionality, and restorative justice as responses to addiction, homelessness, and poverty. In this way, antisocial behavior policy transcends crime and links the government with wider social problems. The focus on antisocial behavior permits the regulation of individual lifestyles, dress, and behavior, while encouraging development of self-policing activities.

On reflection, we can see that each of these three "pillars" of the criminal justice system has changed considerably-particularly in the past two or three decades-and now operates in a way that is noticeably different than its original conception. Arguably, each 
of these pillars is weakened and, in many respects, the original structures have become eroded. Over this period, we have seen a challenge to the operation of the criminal justice system on the grounds that it is not effective, not necessary, and no longer appropriate. In recent years, these challenges have led to changes in the scope of criminal law and criminal procedure. As Ashworth and Zedner (2008) have pointed out, these changes include greater use of diversion, fixed penalties, and summary justice, as well as greater incentives to plead guilty. These changes, they argue, involve a shifting relation between the state and the citizen, as well as changes in the nature of the state itself.

\section{Emerging Crimes}

There is always some variation in the identification, classification, and response to different offenses in different periods. There is also an important distinction, as lawyers remind us, between "law in books" and "law in action." There can be little doubt, however, that recently, the focus on crime has changed significantly and that activities that had little or no relevance twenty or thirty years ago now command our attention. The range of new or emerging crimes is daunting. For our purposes, however, we will concentrate on three relative new crimes-cybercrime, environmental crimes, and terrorism.

\section{Cybercrime}

Cybercrime has become a high-volume crime in the UK and elsewhere, impacting more of the public than traditional forms of acquisitive crime. In the UK, there were 3.2 million fraud offenses in 2017-2018, including 1.7 million cyber-related offenses (ONS 2018). In various countries, specialist units have been established to deal with the different forms of cybercrime. In Britain, there is the Police Central Crime Unit and the National Cybercrime Unit based in the National Crime Agency. These police units involve significantly different forms of organization and intervention than traditional policing structures, and they require the development of new skills, new technologies, and different personnel.

Despite attempts to provide a meaningful response to online fraud, a series of reports in the UK has been highly critical of the police response to online fraud. A report in 2015 by the HMIC found that very few police officers "understood their own roles and responsibilities or those of their force in relation to the investigation of fraud." Most of these online cases of fraud are not dealt with directly by the police but are referred to a specialist agency, Action Fraud, who log calls. Because it is very difficult to track down the offenders, however, there is little in the way of follow-up to these reports. Consequently, there is little information available about the identification and prosecution of offenders, but it is apparent that only a small percentage of these cases are actually investigated. In many cases, online victims receive compensation from the financial institutions involved. This raises an issue about the "victim" status of people in cases in which they experience no personal financial loss. There is also a significant change taking place in the victim-offender relationship with victims being drawn from a relatively wide social spectrum. The offender, on the other hand, is unlikely to be poor and marginalized; instead, he or she tends to be educated, computer literate, and capable of identifying suitable victims.

Yar (2013) has pointed to a trend toward "dispersed and pluralised governance" in relation to the policing of the Internet. This involves a transition away from a state-centered "top down" strategy to a more diversified approach that encompasses a wide range of non-state actors, including commercial bodies, voluntary organizations, citizen-focused 
partnerships, as well as individual citizens in their families. Similarly, Wall (2013) has identified a multi-tiered assemblage of networks that seek to control, direct, and regulate online behavior. These strategies involve social media providers that can identify offenders and, in some cases, remove them from their platforms (Wall and Williams 2013). There are also apps that enable users to report suspicious behavior. These modes of regulation and intervention are a far cry from traditional policing practices.

\section{Environmental Crime}

Green criminology - the study of crimes and harms to the environment - has changed from a fairly marginal area of interest twenty or thirty years ago to a mainstream subject and central area of concern (see, e.g., Brisman and South 2019). Like other emerging "crimes," it involves a movement away from purely legal and criminological concerns into the wider area of "harms." Second, it involves increasingly broader economic, political, and social issues requiring a shift from "criminal justice" to "social justice." The growing interest in green criminology derives from the process of globalization, the intensification of capitalist production, and related anxieties over air and water pollution, climate change and global warming, food contamination, and a wide range of issues that are seen to have an impact at every level of social life (South and Brisman 2013).

Most countries have an environmental protection agency that regulates environmental crime through the administration of environmental protection legislation, the monitoring of environmental quality, and by conducting research (White 2012). The regulatory apparatus of the State relies on remedies, such as administrative measures, civil procedures, and criminal prosecution, as the means by which to encourage conformity. In many countries, the mandate of environmental protection agencies is not only to endorse compliance through the use of criminal prosecutions, but to forge strategic alliances and working partnerships with industry, local governments, and communities. One reason for forming such alliances is that mobilizing prosecutions can be a time-consuming and expensive process.

In some cases, the traditional victim-offender relationship is reversed with the offender being a business corporation and, in some cases, the state, while victims are drawn from across the social spectrum. Some forms of environmental harm fall virtually on entire human populations, whereas other harms, such as some forms of contamination and pollution, tend to fall predominantly on poor and disenfranchised committees and groups. Importantly, victimization is typically a collective rather than individual experience-and those actions against offenders consequently involve different and, at times, complex forms of organization. In terms of regulating environmental offenses, the powers required exceed the capacity and competence of the uniformed police. Although there is a substantial amount of legislation relating to environmental harms, there are difficulties in using criminal law against environmental offenders.

Bringing charges against corporations is particularly difficult. Often, no one person can be held responsible for the actions of the company, while organizations are adept at defending themselves and their interests and have the resources to resist and contest prosecutions. Consequently, in some countries, authorities have introduced alternative sentencing mechanisms that allow the court to order the offender to undertake work to repair the damage to the environment. In this way, the aim is to bring offending parties and the community together. Civil penalties have been employed in some jurisdictions, which are seen to provide a more efficient and cost-effective way to sanction these offenses. 


\section{Terrorism}

The very nature of terrorism demands a global response, and we have seen the development of a plethora of international agencies over the last two or three decades that have been set up to deal with terrorism. Although it is the case in the UK that the police are primarily responsible for dealing with terrorism, the reality is that the "war against terror" is conducted on a number of fronts (Home Office 2018).

In the 1980 s, the issue of terrorism was, to a large extent, seen to be associated with foreigners. In recent years, however, it has become evident that most of those involved in terrorist activities in Europe and the US are homegrown. The majority of terrorist attacks in the US, for example, are not carried out by Muslims. In fact, the majority are US citizens with some 70\% being "lone wolf" attacks (Becker 2014; Hamm 2015; McCulloch et al. 2019). Instead of being recruited from extremist groups, it seems more likely that potential terrorists are drawn from institutions, such as prisons and universities. Consequently, de-radicalization strategies have been developed, although such interventions have been selective with limited effects (Schmid 2013).

On the international level, financial controls and the closing of bank accounts have been undertaken in order to dismantle the assets of terrorist organizations. In Europe, Europol plays the central role in coordinating international responses of different agencies (Cottee 2015). In terms of intervention, there have been two main strategies-intelligence-led policing (ILP) and community policing. Although the Metropolitan Police and other forces pay lip service to ILP, there is a lack of clarity about what it means and how it should be implemented - and, more importantly, how this model can be used strategically to combat terrorism (McGarrell et al. 2007).

Community policing, on the other hand, was promoted as a response in the UK to homegrown terrorism and the perceived need to engage with the Muslim community, in particular, on the assumption that gathering information from informed members of the community provides a potentially valuable resource. These efforts, however, have been relatively short-lived and have proved to be largely ineffective. The Muslim community-having been neglected for many years - are understandably suspicious of policeled initiatives that involve a form of selective collaboration (Klausen 2009; Mulinari 2019).

The "war against terror" is also being fought at the level of ideology, and there is a widespread international initiative to combat terrorist propaganda (and replace it by anti-terrorist propaganda). This involves hacking into terrorist websites and blocking undesirable material. In terms of the ideological battle, certain radical individuals have either been deported or are monitored closely. Identifying terrorists (or potential terrorists) is a notoriously difficult task, however. According to the American Psychological Society, terrorists are neither pathological subjects nor simply rational actors. Rather, they are often driven by a wide set of motives often linked to a sense of injustice among disenfranchised populations. Terrorism has been described as the "warfare of the weak" and typically involves young men who lack the political and material resources to effect change in conventional ways (Hamm 2015).

Since the passage of the Terrorism Act in the UK in 2010, there have been a number of amendments that have systematically expanded police powers. These additions include incitement to terrorism, providing assistance to terrorists, and providing instruction in the use of firearms and explosives. Suspected terrorists are also subject to a special regime of pre-charge detention. This includes not only longer maximum periods of 
detention but also restrictions on obtaining legal advice in certain circumstances. Thus, responding to terrorism requires a significantly different set of strategies than those used to combat "normal crime." The problems of identifying offenders and potential victims not only points to the limitations of traditional policing methods, but it also calls for the development of interventions that involve a range of specialist state and non-state agencies.

Ericson (2007) has suggested that the new forms of regulatory and private policing entail the creation of new policing networks involving a reconfiguration of the rules of police work. This reconfiguration involves operating without conventional rules of criminal law. This form of "counter-law," as he calls it, involves the passing of laws that negate traditional principals, standards, and procedures of criminal law, on the one hand, while facilitating direct behavioral control through surveillance and monitoring mechanisms, on the other. Although presented as a "state of exception," it is the case that it has become the normal state, producing "surveillant assemblages" that operate outside of traditional rules (Ransley and Mazerolle 2009).

\section{Implications and Discussion}

Probably, the most immediate implication of the development of "new crimes" is the changing relationship between victims and offenders. The new generation of offenders, in particular, are now much less likely to be drawn from the ranks of the underclass. Instead, such offenders may be organized, skilled, and well-resourced. By the same token, although victimization remains concentrated on the vulnerable and the accessible, there is growing evidence that victims can be found across the social spectrum. These victims and offenders often involve groups and communities, which has resulted in calls for new forms of collective action. Unlike "normal crime" or "street crime," these "new crimes" tend to involve broader sociopolitical issues, raising questions of social justice rather than simply criminal justice.

In this changing context, there arise pressing issues about the explanatory value of the existing array of criminological theory. Arguably, many of these theoretical explanations were always relatively limited, partial, and selective (Cullen 2011; Matthews 2009; Young 1986). The shift toward an understanding of "new crimes," however, requires a fundamental rethinking, particularly because the changes outlined above are much more diverse and wide ranging, for example, than the recent focus on risk analysis and the exaggerated claims that this involves a paradigm shift in criminology (Feeley and Simon 1994; HannahMoffat 2005).

Policing "new crimes" increasingly involves setting up national and international specialist units involving state and non-state agencies. Traditional policing methods appear increasingly anachronistic and, in many cases, make little impact on these "new crimes." Although in some cases there has been an increase in police powers to provide a response to emerging crimes, new modes of regulation are required that move beyond traditional policing practices and involve the development of new technologies by specialist agencies. A recurring feature of many of these "new crimes" is that they involve protracted investigation and continuous monitoring. Many are not simply events but processes. In order to process these cases, there have been significant changes in adjudication and regulation. Both within the criminal justice system and in the wider community, changes are underway to facilitate the prosecution of the new breed of offenders involving more flexible and informal processes while developing new modes of governance. Interestingly, the penalties 
for cybercrime and environmental crimes rarely involve imprisonment but tend to involve fines, informal dispute resolution, and forms of compensation.

As a result of this changing landscape, the question arises as to whether we are moving away from a system of "class justice" to a more diverse and extensive system of crime control. Or is it the case that the regulation of these new crimes will generate a new layer of intervention that will simply overlay and complement the existing system? In addition, will the traditional focus on crime be replaced by a preoccupation with security?

There are signs that traditional forms of policing with its focus on "street crime" and the underclass appear increasingly outdated, particularly in a period involving a substantial decrease in recorded crime. At the same time, the argument presented by Deleuze (1995) that we are moving away from a reliance on controlling institutions toward more open and flexible forms of surveillance and monitoring appears increasingly plausible. In this postdisciplinary world, he argues that control will become more continuous and diverse and open-ended.

It is always a challenge in a period involving a multitude of rapid shifts in social relations to develop a clear picture of the real direction and meaning of change. There can be little doubt, however, that that which we might call, the "old criminology," with its preoccupation with the poor and the propertyless, is undergoing profound mutation as new forms of transgression are coming to dominate aspects of social and political life, creating new dangers and risks in a world that appears, in many respects, to be becoming more unpredictable and ungovernable.

Open Access This article is licensed under a Creative Commons Attribution 4.0 International License, which permits use, sharing, adaptation, distribution and reproduction in any medium or format, as long as you give appropriate credit to the original author(s) and the source, provide a link to the Creative Commons licence, and indicate if changes were made. The images or other third party material in this article are included in the article's Creative Commons licence, unless indicated otherwise in a credit line to the material. If material is not included in the article's Creative Commons licence and your intended use is not permitted by statutory regulation or exceeds the permitted use, you will need to obtain permission directly from the copyright holder. To view a copy of this licence, visit http://creativecommons.org/licenses/by/4.0/.

\section{References}

Andrews, D., \& Bonta, J. (2010). Rehabilitating criminal justice policy and practice. Psychology, Public Policy and Law, 10(1), 39-55.

Ashworth, A., \& Zedner, L. (2008). Defending the criminal law: Reflections on the changing character of crime, procedure and sanctions. Crime Law and Philosophy, 2(1), 21-51.

Bayley, D. (1994). Police for the future. New York: Oxford University Press.

Becker, M. (2014). Explaining lone wolf target selection in the United States. Studies in Conflict and Terrorism, 37(11), 959-978.

Bottoms, A., \& Preston, R. (1980). The coming penal crisis. Edinburgh: Scottish Academic Press.

Brisman, A. (2004). Double whammy: Collateral consequences of conviction and imprisonment for sustainable communities and the environment. William \& Mary Environmental Law \& Policy Review, 28(2), $423-475$.

Brisman, A., \& South, N. (2019). Green criminology and environmental crimes and harms. Sociology Compass, 13(1), e12650. https://doi.org/10.1111/soc4.12650.

Bryant, C. (1981). Depillarisation in the Netherlands. The British Journal of Sociology, 32(1), 56-74.

Clear, T., \& Frost, N. (2014). The punishment imperative: The rise and failure of mass incarceration in America. New York: New York University Press.

Cottee, S. (2015). Inside Europol's online war against ISIS. VICE April 10th. 
Crawford, A. (2009). Governing through anti-social behaviour. The British Journal of Criminology, 49(6), $810-831$.

Cullen, F. (2011). Beyond adolescent limited criminology; Choosing our future. Criminology, 49(2), 287-330.

Currie, E. (1998). Crime and punishment on America. New York: Metropolitan Books.

Dearden, L. (2018). Police failing to record tens of thousands of crimes, inspection finds. The Independent, 15th February.

Deleuze, G. (1995). Negotiations. New York: Columbia University Press.

Donzelot, J. (1997). The policing of families. Baltimore: John Hopkins University Press.

Downes, D. (1988). Contrasts in tolerance. Oxford: Clarendon Press.

Durlauf, S., \& Nagin, D. (2011). Imprisonment and crime: Can both be reduced? Criminology and Public Policy, 10(1), 13-54.

Elkin, M. (2018). Crime in England and Wales; Year ending June 2018. Office of National Statistics. London: HMSO.

Ericson, R. (2007). Rules in policing. Theoretical Criminology, 11(3), 367-402.

Farrall, G. (2013). Five tests for a theory of the crime drop. Crime Science, 2(1), 1-8.

Farrall, G., \& Pease, K. (2007). Crime in England and Wales. More violence more chronic victims. Civitas, 4(2), 1-8.

Feeley, M., \& Simon, J. (1994). Actuarial justice: The emerging new criminal law. In D. Nelken (Ed.), The futures of criminology (pp. 173-201). London: Sage.

Foucault, M. (1977). Discipline and punish: The birth of the prison. Alan Sheridan (trans.). London: Allen Lane.

Foucault, M. (2009). Alternatives to the prison: Dissemination or decline in social control? Theory, Culture and Society., 26(6), 12-24.

Garland, D. (1981). The birth of the welfare sanction. British Journal of Law and Society, 8(Summer), $29-45$.

Hamm, M. (2015). Lone wolf terrorism in America: Using knowledge of radicalisation pathways to forge prevention strategies. Washington: National Institute of Justice.

Hannah-Moffat, K. (2005). Crimogenic needs and the transformative risk subject: Hybridizations of risk/need in penalty. Punishment and Society, 7(1), 29-51.

Harcourt, B. (1998). Reflections on the subject: A critique of the social influence conception of deterrence, the broken windows theory and order maintenance policing New York Style. Michigan Law Review, 97(2), 21-72.

Hargreaves, J., Husband, H., \& Linehan, C. (2018). Police workforce, England and Wales. London: HMSO.

Hillyard, P., Pantazis, C., Tombs, S., \& Gordon, D. (2004). Beyond criminology: Taking harm seriously. London: Pluto Press.

Home Affairs Select Committee. (2018). Policing for the future: Tenth report of session 2017-19. House of Commons.

Home Office. (2018). Contest: The United Kingdom's strategy for countering terrorism. Cm 9608. London: HMSO.

Hulsman, L. (1986). Critical criminology and the concept of crime. Contemporary Crisis, 10(1), 63-80.

Ignatieff, M. (1978). A just measure of pain: The penitentiary in the industrial revolution 1750-1850. London: Macmillan.

Jacobs, J. (1978). Stateville: The penitentiary in Mass Society. Chicago: University of Chicago Press.

Karmen, A. (2000). The New York murder mystery. New York: New York University Press.

Kelling, G. L. (2001). "Broken windows" and the culture wars: A response to selected critiques. In R. Matthews \& J. Pitts (Eds.), Crime, disorder and community safety (pp. 120-144). London: Routledge.

Kinsey, R., Lea, J., \& Young, J. (1986). Losing the fight against crime. Oxford and New York: Blackwell.

Klausen, J. (2009). British counter-terrorism after 7/7: Adapting community policing to the fight against domestic terrorism. Ethnic and Migration Studies, 35(3), 403-420.

Lane, R. (1992). Urban police and crime in nineteenth century America. Crime and Justice, 15, 1-50.

Laville, S. (2012). Kent police officers arrested over crime statistics irregularities. The Guardian, 15 November. https://www.theguardian.com/uk/2012/nov/15/kent-police-arrested-statistics-irregulari ties.

Martinson, R. (1974). What works? Questions and answers about prison reform. The Public Interest, 35, $22-54$.

Matthews, R. (1992). Replacing broken windows. In R. Matthews \& J. Young (Eds.), Issues in realist criminology (pp. 19-50). London: Sage. 
Matthews, R. (2009). Beyond "so what?" criminology: Rediscovering realism. Theoretical Criminology., 13(3), 331-362.

Mauer, M., \& Chesney-Lind, M. (2003). Invisible punishment: The collateral consequences of mass imprisonment. New York: The New Press.

Mayhew, H. ([1851] 1961). London labour and London poor. London: George Woodfall and Son.

McCulloch, J., Walklate, S., Maher, J. M., Fitz-Gibbon, K., \& McGowan, J. (2019). Lone wolf terrorism through a gendered lens: Men turning violent or violent men behaving violently? Critical Criminology: An International Journal, 27(3), 437-450. https://doi.org/10.1007/s10612-019-09457-5.

McGarrell, E., Freilich, J., \& Chermal, S. (2007). Intelligence led policing as a framework for responding to terrorism. Journal of Contemporary Criminal Justice, 23(20), 142-158.

McLennan, R. (2008). The crisis of imprisonment; Protest politics and the making of the American penal state, 1776-1941. Cambridge: Cambridge University Press.

Milkhailova, A. (2018). Police have targets to investigate fewer reported crimes. The Telegraph, 2nd October.

Millie, A., \& Herrington, V. (2005). Bridging the gap: Understanding reassurance policing. The Howard Journal, 44(1), 41-56.

Mulinari, L. S. (2019). The spectrum of repression: Swedish Muslims' experiences of anti-terrorism measures. Critical Criminology: An International Journal, 27(3), 451-466. https://doi.org/10.1007/ s10612-019-09462-8.

Murray, C. (1997). Does prison work?. London: IEA Health and Welfare Unit.

Nagin, D. S. (1998). Criminal deterrence: Research at the outset of the twenty-first century. Crime and Justice, 23, 1-42.

Offe, C. (1984). Contradictions of the welfare state. London: Hutchinson.

ONS (2018). Focus on violent crime and sexual offences, England and Wales. Office of National Statistics.

Piquero, A., \& Blumstein, A. (2007). Does incapacitation reduce crime? Journal of Quantitative Criminology, 23(4), 267-285.

Ransley, J., \& Mazerolle, N. (2009). Policing in an era of uncertainty. Police Practice and Research, 10(4), 365-381. https://doi.org/10.1080/15614260802586335.

Robinson, G. (2008). Late modern rehabilitation. Punishment and Society, 10(4), 429-445.

Rusche, G., \& Kirchheimer, O. (2003). Punishment and social structure. New Brunswick, NJ: Transaction Publishers.

Schmid, A. (2013). Radicalisation, de-radicalisation, counter-radicalisation: A conceptual discussion and literature review. ICCT Research Paper. The Hague, March.

Shearing, C. (1992). The relationship between public and private policing. In M. Tonry \& N. Morris (Eds.), Modern policing (pp. 399-434). Chicago: University of Chicago Press.

South, N., \& Brisman, A. (2013). Routledge international handbook of green criminology. Abingdon, Oxon, UK: Routledge.

Stenning, P. (1989). Private police and public police: Toward a redefinition of the police role. In J. Loree (Ed.), Future issues in policing (pp. 169-192). Chicago: University of Chicago Press.

Storch, R. (1975). The plague of blue locusts: Police reform and popular resistance in Northern England 1840-57. International Review of Social History, 20(1), 61-90.

Sutherland, E. (1949). 'Is White Collar Crime, Crime? American Sociological Review, 10(2), 132-139.

Tappan, P. (1947). Who is the criminal? American Sociological Review, 12(1), 96-102.

Tonry, M. (2008). Learning from the limitations of deterrence research. Crime and Justice, 37(1), 279-308.

Turanovic, J., Rodriguez, N., \& Pratt, T. (2012). The collateral consequences of imprisonment. Criminology, 50(4), 913-959.

Vitale, A. (2017). The end of policing. London: Verso.

Walby, S., Towers, J., \& Francis, B. (2016). Is violent crime increasing or decreasing? The British Journal of Criminology, 56(6), 1203-1234.

Wall, D. (2013). Policing identity crimes. Policing and Society, 23(4), 437-460.

Wall, D., \& Williams, M. (2013). Policing cybercrime: Networked and social media technologies and challenges for policing. Policing and Society, 23(4), 409-412.

Ward, T., \& Maruna, S. (2008). Rehabilitation. London: Routledge.

White, R. (2012). Environmental issues and the criminological imagination. Theoretical Criminology, 7(4), 483-506.

Whitehead, T. (2012). Police fail to solve three in four crimes. The Telegraph, 21 July. https://www.teleg raph.co.uk/news/uknews/law-and-order/9415793/Police-fail-to-solve-three-in-four-crimes.html.

Wilson, J., \& Kelling, G. (1982). Broken windows: Police and neighbourhood safety. The Atlantic Monthly, 12(March), 29-38. 
Yar, M. (2013). The policing of internet sex offences: Pluralised governance versus hierarchies of standing. Policing and Society, 23(4), 482-497.

Young, J. (1986). The failure of criminology and the need for radical realism. In R. Matthews \& J. Young (Eds.), Confronting crime (pp. 4-30). London: Sage.

Young, J. (1994). Incessant chatter: Recent paradigms in criminology. In M. Maguire, P. Morgan, \& R. Reiner (Eds.), The Oxford handbook of criminology (pp. 69-124). Oxford: Oxford University Press.

Publisher's Note Springer Nature remains neutral with regard to jurisdictional claims in published maps and institutional affiliations. 